\title{
A Disaggregated Model of World Production and Trade: An Estimate of the Impact of the Tokyo Round
}

\section{Alan V. Deardorfi and Robert M. Stern, University of Michigan}

We present in this papet a computational model of work production, trase, and employment that is disageiezated by country and sector and repor: on tie application of the model to the changes in tariffs anc quantifiable nontarif tarriers te gutiated in the Tokyo Round that was concluded in 1979 The model incorporates supl ly and demand functions and naarket-clearing conditions for 2,2 tradable incustries, slus $n$ arke is for 7 nontradabl: industries, in each of the 18 major industrialized courtries and 10 major developin? countries. The equations of the model are presented in the ext anc the explicit functional forms in an appendix. The implementation of the model is ciseussed triefly.

Application of the model to the Tokyo Round sugge ite $\$$ that there will be small but beneficial effects on trade, domes di prices, and economic $v_{i}$ 'fare in practically all the major industrialized countries and in some of the major developing countries. Because mar.y of the NTB codes negotiated in the Tokyo Round were stated in advisory terns, their impact cannot be evaluated unambiguously at present. Further, inany existing NTBs of importance were exempted altogether from the nugotiations. The Tokyo Round must be viewed accordingly as having dealt with a somewhat limited part of all inis rferences with trade.

In this paper, we describe a disaggreşated model c $f$ world production and trade and report on its application to the changes in tariffs and non:ariff harriers that were negotiated in the Tokyo Round of multilateral trade negotiations concluded in 1979. Although our model was originally desigred to study the effects of multilateral tariff reductions, ${ }^{\prime}$ it also includes several additional exogenous variables which allow us to study orher problems. ${ }^{2}$ The current version of the mocel includies, besides tariffs,

Address correspondence to: Rob." "M. Stern. Department of Economics, The University of Michigan, Ann Aibor, MI 4816.

'See Deardorff and Stern (1979), where an 18-country versic of the nodel was used to study the tariff and nontariff barrier reductions negotiated in the lokyo Round. As will be made clear below. the microeconomic focus siour mudel distingaisnes it from the macro oriented world linkage systems typified by the LINK, DEGMIS a... METEOR models. These latter models are also highly aggregated in terms of their sectoral ccuerage within countries.

${ }^{2}$ Gee Deardorft et al. (1979), where the effects of exchang rate c hanges are presented and Deardorff and Stem $(1980 a, b)$ for analyses of the ciects of change s in vade on croployment and changes in the structure oi protection under fixed ano flexible exchange rates in the major industrialized countries. 
taxes on exports and home production, quantitative restrictions on trade, a variable to represent government p:ocurement risgulations, and a facility for making the volume of trade exogenous. The model can be solved under a variety of assumptions about exchange regimes, including, in addition to fixed and flexible exchange rates, the possibility of pegging to a basket of currencies and the use of import licensing. And finally, we include a chas acterization of labor markets in which wages can be either exogenous or endogenous at the country or industry level.

\section{EQUATIONS OF THE MODEL}

The complete model, though without functional forms, is presented as equations 1-17 in Table 1. Functional forms appear in the Appendix and will be explained below.

The model includes $m$ countries, $i=1, \ldots, m$, producing anc trading $n$ gockis, $j=1, \ldots, n$, and producing an additional $\left(n^{\prime}-n\right)$ nüntradable goodis, $j=n+1, \ldots, n^{\prime}$. A distinguishing characteristic of our model, however, is that both producers and consumers distinguish, within tradsble industries, between home goods, which are produced and used domestically, and those that are either exported or importerl.

Thus, within eevit country and tradable industry, producers are separated into a home sector and an expcrt sector. Each has its own supply function, ieflecting certain fixed factors of production that cannot easily be transferred between the sectors. This nontransferability may result from locational requirentents or from the need to tailor products to natiorial markets, though these features are not explicit in our model.

Demanders, too, differentiate between home-produced and imported products of a given tradable industry. Consumers, as well as producers who deniand intermediate inputs, are assumed to regard home-produced and imported goods as imperfect substitutes, but imports from various foreign countries as perfect substitutes. ${ }^{3}$ Thus, demands for imports and home-produced goods are separate, but depend on the prices of both.

Three separate prices obtain in each country, $i$, for each tradable industry, $j=1, \ldots, n$. First, a home price, $p_{i j}^{H}$, is paid by users and received by producers in the home sector. ${ }^{4}$ It is determined by the equality of honesector supply and Jemand in equation 8 . The second and third prices are those received for exports, $p_{i j}^{X}$, and those paid for imports, $p_{i j}^{M}$. All countries face a common world price, $p_{j}^{W}$, in each tradable industry, anc it is

\footnotetext{
${ }^{3}$ Ideally, we would like imports from different countries to be imperfect substitutes as well. However, data limitations and the diffsulty of solving a more general model prevented this.

${ }^{4}$ Actually, if the tax on home production $\left(1-t_{i j}^{H}\right)$, is not zero, producers receive only $t_{j j}^{h} p_{i j}^{h}$
} 
Table 1: Equations of the Moce!

\section{Country System Equations}

Supply functions of products for ex rort

$$
\begin{aligned}
S_{i j}^{X}= & S_{i j}^{X}\left(p_{i j}^{X}, p_{i}^{H}, \ldots, p_{i n}^{H}, p_{i 1}^{M}, \ldots, p_{i n}^{M}, w_{i j}, K_{i j}^{X}\right), \\
& i=1, \ldots, m, \quad J=1, \ldots, n .
\end{aligned}
$$

Supply functions of produ:ts for home use

$$
\begin{aligned}
S_{i j}^{H}= & S_{i j}^{H}\left(t_{i j}^{H} p_{i j}^{H}, p_{i 1}^{H}, \ldots, p_{i n}^{H}, p_{i}^{M}, \ldots, p_{i n}^{M}, w_{i j}, K_{i j}^{H}\right), \\
& i=1, \ldots, \quad j=1, \ldots, n^{\prime} .
\end{aligned}
$$

Demand functions for imported goods

$$
\begin{aligned}
D_{i j}^{M}= & D_{i j}^{M}\left(p_{i j}^{M}, p_{i j}^{H}, E_{i},\left[P_{i}^{H}\right] S_{i 1}^{H}, \ldots,\left[p_{i n}^{H},\right] S_{i r,}^{H},\right. \\
& {\left.\left[p_{i 1}^{X}\right] S_{i}^{X}, \ldots,\left[p_{i n}^{X}\right] S_{i n}^{X}, G_{i j}\right), \quad i=1, \ldots, m, \quad j=1, \ldots, n . }
\end{aligned}
$$

Demand functions for home-p..:duced goods ${ }^{a}$

Tradables:

$$
\begin{aligned}
D_{i j}^{H}= & D_{i j}^{H}\left(p_{i j}^{H}, p_{i j}^{M}, E_{i},\left[p_{i 1}^{H}\right] S_{i}^{H}, \ldots,\left[p_{i n}^{H} \cdot\right] S_{i n}^{H},\right. \\
& {\left.\left[p_{i 1}^{X}\right] S_{i 1}^{X}, \ldots,\left[p_{i n}^{X}\right] S_{i n}^{X}, G_{i j}\right), \quad i=1, \ldots, m, \quad j=1, \ldots, n . }
\end{aligned}
$$

Nonir adables:

$$
\begin{aligned}
D_{i j}^{H}= & D_{i j}^{H}\left(p_{i j}^{H}, E_{i},\left[p_{i}^{H} \mid S_{i}^{H}, \ldots,\left\lfloor p_{i n}^{H},\right] S_{i n}^{H},\left[p_{i}^{X} \mid S_{i}^{X}, \ldots,\left[p_{i n}^{X}\right] S_{i n}^{K}\right),\right.\right. \\
& i=1, \ldots, m, \quad j==n+1, \ldots, n^{\prime}
\end{aligned}
$$

Export frices

$$
p_{i j}^{X}={ }_{i}^{Y}{ }_{i j} R_{i} p_{j}^{W}, \quad i=1, \ldots, m, j=1, \ldots, n .
$$

Import prices

$$
p_{i j}^{M}=t_{i}^{M e q} R_{i} p_{j}^{W}, \quad i=1, \ldots, m, \quad j=, \ldots, n .
$$

Consumer expenditure and tarif. revenue

$$
\begin{aligned}
& F_{i}=E_{i}^{O}+\sum_{j=1}^{n}\left(t_{i j}^{M e q}-1\right) R_{i} p_{j}^{W} D_{i j}^{M}+\sum_{j=1}^{n}\left(1-t_{i}^{\lambda(i)}\right) R_{i} \nu_{j}^{\prime \prime} s_{i j} \\
& +\sum_{j=1}^{n^{\prime}}\left(1-t_{i j}^{H}\right) k_{i}, i_{j}^{\prime}, \quad i=1, \ldots, m .
\end{aligned}
$$

Market equilibrium for home goods

$$
S_{i j}^{H}=D_{j}^{H}, \quad i=1, \ldots, m, \quad j=1, \ldots, n^{\prime} .
$$

Tarijj Equivalents

To reflect quantitative restrictions:

$$
t_{i j}^{M} t=t_{i j}^{M i e q}\left(t_{i j}^{M}, D_{i j}^{M}, Q_{i j}^{M}\right), \quad i=\vdots, \ldots, m, j=1, \ldots, n .
$$


To reflect import licensing:

$D_{i j}^{M}=L_{i j}\left(\sum_{k=1}^{n} p_{k}^{W} S_{i k}^{K}+B_{i}^{K O}\right), \quad i=1, \ldots, m, j=1, \ldots, n$.

To determine exogenous imports:

$D M=D_{i j}^{M O}, \quad i=1, \ldots, m, \quad j=1, \ldots, n$.

Export tax equivalents

To reflect quiantitative restricions:

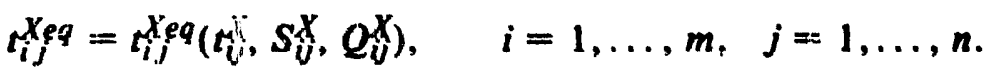

To determine exogenous exports:

$S_{i j}^{X}=S_{i j}^{X O}, \quad i=1, \ldots, m, j=1, \ldots, n$.

Demand for labor by industry ${ }^{a}$

Tradables:

$D_{j}^{H}=D_{i j}^{f}\left(\left[w_{i j}\right],\left[p_{i j}^{X}\right],\left[p_{i j}^{H}\right], s_{i j}^{X}, s_{i j}^{H}, K_{i j}^{X}, K_{i j}^{H}\right)$

$$
i=1, \ldots, m, j=1, \ldots, n \text {. }
$$

Nontradables:

$D_{i j}^{H}=D_{i j}^{H}\left(\left[w_{i j}\right],\left[p_{i}^{H}\right], S_{i j}^{H}, K_{i j}^{H}\right)$

$$
i=1, \ldots, m, j=n+1, \ldots, n \text {. }
$$

\section{Labor markets}

Exogenous wages:

$w_{i j}=w_{i}^{Q}, \quad i=1, \ldots, m, j=1, \ldots, n^{\prime}$.

Country-wide labor rarket:

$\sum_{j=1}^{n^{\prime}} D_{i i}^{\prime}=S_{i}^{L O}, \quad w_{i i}=w_{i k} \quad i=1, \ldots, m_{,} j \neq k=1, \ldots, n^{\prime}$.

Industry labor rnarkex:

$D_{i j}^{h}=S_{i j}^{L}, \quad j=1, \ldots, m, j=1, \ldots, n^{\prime}$.

Net exports

$$
N_{i j}^{X}=S_{i j}^{X}-1 D_{j}^{M}, \quad i=1, \ldots, m . j=1, \ldots n .
$$

\section{World System Equations}

Market equilibrium for traded goods

$$
\sum_{i=1}^{n} N_{i j}^{K}+N_{j}^{\text {row }}=0, \quad j=1, \ldots, n .
$$




\section{Table 1: Cont.}

Trade balances

$$
B T=\sum_{j=1}^{n} p_{j} N_{j}, \quad i=1, \ldots . n .
$$

Rest-of-world net supply

$$
\left.N^{\text {ow }}=M^{\text {ow }}(p), \ldots, p_{W}^{W}, R_{1}, \ldots, R_{m}\right), \quad j=1, \ldots, n \text {. }
$$

\section{Exchange rates}

\section{Fixed rates:}

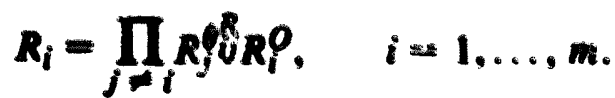

Flexible rates:

$$
B_{i}^{T}+B_{i}^{K O}=0, \quad R_{m}=R_{m}^{O}, \quad i=\ldots, \ldots m-1 .
$$

\section{Notation}

\section{Endagenous Variables:}

$S_{W}^{X} . S_{H}^{H}=$ Supply of good $j$ by country $i$. export and home sectors, respecivels.

DY, of $=$ Demand for good $j$ in country $i$, imported and home-produced, respectively. $p_{y}^{X}, p_{y}=$ Domestic price of good $j$ in country $i$, exported and imported, respectively.

pH = Home-sector prics of good $j$ in country $i$.

$p_{j}^{W}=$ World price of good $j$.

$E_{i}=$ Consumer expenditure in country $i$.

$B T=$ Balance of trade of country $i$.

$\boldsymbol{R}_{i}=$ Exchange rate of country $i$ (domes tic currency per unit of world currency).

$D f=$ Demand for labor by industry $j$ in country $i$.

$w_{i j}=$ Wage of labor in industy $j$ in country $i$.

tife, $19 f^{\text {eq }}$ Export tax and tari equivalents in industry $j$ iq country $i$, respectively.

$N X$ Net expors of industry $j$ in country $i$.

$N^{\text {iow }}=$ Rest-of-wor d net supply in industry $j$.

\section{Exogenous Variables:}

$\boldsymbol{K}_{\hat{U}}^{X}, \boldsymbol{K} H=$ Capitai stock of industry $j$ in country $i_{8}$ export and home sectors, respectively.

$w_{i}^{O}=$ Mcney wage in country $i$, if exngenous.

$t y=1$ plus the ad valorem tariff on imports of gomd, into country $i$.

$M_{i}, t_{y}^{H}=1$ minus the ad valorem tax on cxports and home production, respectively. in industry $j$ of country $i$. 
Table 1: Cont.

$G_{i j}=:$ Shift parameter representing governmant procure nent in ilidustry $j$ in country $i$.

$E_{i}^{Q}=$ Exogerous component of exf enditure in country $i$.

$R_{i}^{Q}=$ Exogenous exchange rate.

$B_{i}^{K C}=$ Exogenous capital inflow in country $i$.

$Q_{i j}^{X}, Q_{i j}^{M}=$ Shift parameter for quantitative restrictions on exports and imports, respectively, in industry $j$ in country $i$.

$D_{i j}^{M O}, S_{i j}^{X O}=$ Imports and exports, respectively, of industry $j$ in country $i$, if exogenous.

$S_{i}^{L O}, S_{i j}^{L O}=$ Country $i$ and industry $j$ supplies of labor.

$\theta_{i j}^{R}=$ Weight used in pegging currency of country $i$ to that of country $\therefore$

${ }^{a}$ Square brackets indicate variables which appear only with Cobb- Douglas specification of technology.

determined in a world market to be described below. Export and import prices are obtained from this in equations 5 and 6 by using exchange rates, $\boldsymbol{R}_{i}$, and export tax and tariff-equivalent variables to be explained below.

Equations 1-4, then, present supply and demand functions in terms of these prices, plus wages, expenditure levels, and various exogenous shift parameters. Supplies depend on all home andimport prices, and demands depend on all supplies, toth to reflect the use of intermediate inputs to production.

All tax and tariff revenue is assurned to be redistributed to consumers anc spent. Thus, expenditure is given in equation 7 as this revenue plus an exogenous component. With this formulation we avoid a more detailed characterization of macroesonomic isues by making effective expenditure exogenous.

The remaining equations for each country, 9-13, determine tariff and export tax equivalents, labor demands and wages, and net exports. The rirst of these include several cases that will be explained below. There are also three different assumptions mads about labor markets, but these should be self-explanatory from the table. Net exports $n$ each industry are just the difference between export supplies and inmport demands, and it is these that feed into the world-system equations, 14-17, whese world prices and exchenge rates, if flexible, are determined.

Focusing on the worlt-system equations, note first that equilibrium in world markets for traced goods is required in equation 14 , where the sum 
of these net exports plus net supply from the rest of the wor id is set equal to zero. This determines world prices, $p_{i}^{W}$. Next, the values of net exports are added over industries to form each country's balaince of trade in equation 15. Rest-of-world net supply in each industry is deternined in equation 16 as a simple and rather ad hoc function of world prices and exchange rates.

Finally, the exchange rates are determined in ecuations 17 , with separate zases for fixed and flexible exchange-rate regimes. For any country with a pegged exchange rate, equation 17 a sets it equal to an index of other-country rates. Depending on the weights in this index, the peg may either be to a basket of currencies or to a particular currency. For any country with a flexible exchange rate, on the other hanc, $17 \mathrm{~b}$ determines it by the requirement that its balance of trade plus an exogenous capital inflow be equal to zero.

Oniy $m-1$ markets need to be cleared explicitly, due to Walras' Law. ${ }^{5}$ However, to determine absolute prices and exchange rat ve nust then specify a numeraire. This is rone in the last of equations $(. i 0)$, where we fix the exchange rate of country $m$.

Since exogenous capital flows are specified in units of the numeraire, the selection of $m$ is not trivial. In applying the model, we have chosen the United States dollar as the numeraire, which means that tibe dollar values of capital flows are assumed to be constant.

\section{SUPPLY AND DEMAND FUNCTIONS}

We derived explicit supply and demand functions from utility and profit-maximization of consumers and firms, assuming explicit utility and production functions. Details of these derivations are contained in a working paper, which can be consulted (Deardorff et al. 1976). Here we merely report the assumptions that were made and list the results in the Appendix.

Since both producers and w, onsumers demand goods, and since each tradable industry has both imp.urted and home-produced goods avaiiable, we first characterized the choice between the two. This was done, for each indistry, with functions that aggiegate the services of home and imported gonds. These then enter as ar:gunients $i: 1$ buth utility and production functions. To permit choice of the degree of substitution between home

\footnotetext{
${ }^{5}$ For consistency we speciîy the solal value of resi-of-woild net supplies as equal to the sum of exogenous capital inflows. It then follows from equations $14-17$ th t $B_{i n}^{T}+B_{m}^{K O}=0$. This means, as Walras' Law would suggest, that equilibrium in all but the $n$th currency market implies equilibrium in it as well.
} 
and imported goods, these aggregation functions were specified as Constant Elasticity of Substitution (CES) functions. The substitution elasticities for each industry were then inferred from published econometric estimates of import-demand elasticities. ${ }^{6}$

To obtain consumer demand functions, we used a Cobb-Douglas utility function. Its arguments were nontradable consumption levels plus these aggregates of horne and imported tradable goods. By maximizing this utility function for a given level of expenditure, we obtained consumer demand functions for each industry.

It will be rivied that the demands depend only on expenditure and on home and import prices of the own industry. Prices from other industries do not appear, since Cobb-Douglas utility forces $c$ oss elasticities of demand to be zero.

For firms, we assumed prodution functions whose arguments were again these hume-import aggregates for each industry plus an aggregate of primary factors as well. The aggregate function for primary factors (labor and capital) was also specified as CES.' These aggregates wer: related by fixed coefficients in the primary version of the model, though we have also used a $\mathrm{Cobb}-D o u g l a s$ technology, which permits more substitution among the inputs. The model can acconimodate different inputoutput duta for each countuy. However, we have so far been unable to gather and process that mich data. Instead, we have used tables for only the United States and Brazil for all of the industrialized and developing countries, respectively, in the model.

By solving profit-maximization problems for firms, given their production technologies and capital stocks, we obtained supply functions for the export and home sectors, demand functions for home and imported intermediate inputs, and demand functions for lahor. Unlike consumer demand functions, the firm supply functions depend on prices in all industries, since all may provide intermediate inputs. Also, while firm demand functions do not directly involve cross-price effects, they do have such effects indirectiy, since they depend on supplies, which in turn depend on all prices.

The main difference between the two specifications of technology is that

\footnotetext{
${ }^{6}$ These elasticities are surveyed in Stern et al. (1976). To infer elasticities of substitution from the estimates, we first used our model to derive impurt demand elasticities in terms of substitution elasticities and measurable parameters such as import shares. The result was then solved for the substitution elasticities. Details are contained in Deardorff et al. (1976).

${ }^{7}$ Elasticities of substitution between capital an 1 labor were raken from Zarembka and Chernicoff (1971). Shares of value added and intermediate inputs were obtained from the 1972 U.S. input-ouiput table and the 1970 Brazilian table.
} 
input-demand functions for Cobb-Douglas technology depend directly on output price and, for labor, on the wage. With fixed coefficients, cutput alone determines the demand for all inputs except for the livision between home goods and imports. But with substitution allowed, the prices of inputs relative to output matter for input demands, even once the level of output is known.

A further difference is also worth noing. Own-price elasticities of supply and demand are all somewhat larger with Cobb-Douglas technology than with fixed coefficients, as one would expect with increased substitution.

The supply and demand functions of firms and consumers have been aggregated to set the sxplicit versions of equations $1-4$ and 11 that appear in the Appendix.

\section{NONTARIFF BARRIERS}

We modeled the presence of quantitative ! astrictions ( $Q R s$ ) on imports by using tariff equivalents, $t_{i j}^{\text {Meq }}$, that vary endogenously to dampen the quantitative response of $i$ mports to changes in other variables. We also include a similar facility for handling QRs on exports, through an exporttax-equivalent variable, $t_{i j}^{X e q}$, though we have not yet had much occasion to use this.

The tariff equivalent is defined as a wrighted average of the nomina: tariff variable, $t_{i j}^{M}$, and a second implicit tariff variable, $q_{j} M$, that would reflect binding QRs for the entire industry. The weights are given by the fraction of the industry in which QRs are binding. The implicit tariff is defined as one that would, in a typical import demand equation, keep the quantity demanded equal to an exogenous value, $Q_{i j}^{M}$, set by a quota. The result, as shown in the Appendix, is a simple expression relating the tariff equivalent to the nominal $t \mathrm{t}$ rif and to the difference betweer ine quota and import demand.

A rise in the quantity of permitted imports lowers the tariff aquivalent and does in fact stimulate ir ports. On the other hand, chunges (such as a fall in the world price) that vould normally increase den'and $t$ imports will cause the tariff equivalent to rise and so cause the change in quantity to be smaller than it would otherwise be. Similar remariss af oly to the export-tax equivalent, where it should be remembered tha: $t_{i j}^{\text {xet }}$ sactually one minus the export-tax equivalent, which therefore varies inve 'sely with $t_{i}^{\text {Ane }}$.

This formulation permits us to anaiyze problems other than nontariff barriers (NTBs) under the realistic and important assumption that NTBs are present and restrict the responsiveness of trade. This is acconplished 
by merely making the fractions $9 Q_{j}^{M}$ and $\theta_{y}^{Q X}$ nonzero in industries where this is appropriate. In addition, by using the exogenous variables, $Q_{i j}^{M}$ and $Q_{j j}^{K}$, we have been able to analyze the effect of changing a $Q R$, so long as we know the volume of trade that is being released from a binding constraint. This is how we have treated the changes in agricultural quotas in our analysis of the Tokyo Round.

\section{IMPORT LICENSING}

A new feature of the mociel that we felt necessary with the addition of developing countries is the treatment of import licensing. Many of these countries have pegged exchange rates, but they are often unable to finance all of the imports that would be desired at that (or perhaps any) exchange rate and so resort to more direct regulation of import behavior.

We have modeled this again through the tariff-equivalent variable, $t_{i j}^{*}$. For countries where licensing is in effect, we suppress equation $9 a$ and assume instead that $t_{i j}^{M k q}$ incorporates the shadow price of scarce foreign exchange to a particular sector. The government is assumed to allocate the foreign exchange that is earned from exports and capital inflows among importers in proportion to some base level of imports that is establishec. As a result, each sector's imports depend on the total value of exports and capital inflow as shown in the licensing function $L_{i, i}$ of equation $9 \mathrm{~b}$. What this specification does is to assure approximate balance-of-payments equilibrium even though ths exchange rate is pegged.

Along with import licensing, we also $\mathrm{m}$. Jeled a subsidy to exports squal to the export sector's payment of any tariff equivalent on imported inputs. This was done to prevent import licensing from adversely affecting exports through its effect on input prizes. Essentially, we are saying that exporters are exempt from licensing when what they import will contribute to production for export.

\section{REST-OF-WORLD NET SUPPLY}

With the addition of 16 developing countries to our midel, th: importance of the sector representing the rest of the world is correspond. ingly reduced. In the past, we have experimenied with several ways $0^{\circ}$ specifying rest-of-world behavior, but for present purposes we tave usei only one.

We assume that rest-of-world exports in each industry responc positively to the world price with an elasticity, $\varepsilon_{j}^{*}$, that is rypisal of the included countries. Rest-of-world imports are assumed to be subject to import licensing and so are fixed at a constant fraction of the value of rest- 
of-world exports. Exchange rates in the rest of the world are assumed to be pegged to a basket of currencies of the included countries, with weights that depend primarily on their imcortance in trade. As a result, rest-ofworld net exports in any particula- industry depend upon all world prices und exchange rates.

\section{IMPLEMENTATION OF THE MODEL}

The model just decribed is designed to take into account as many as possible of the interconnections among industries and countries at the microeconomis level. This enables us to examine a variety of econonic issues that other models cannot acdress, either because thay are too highly aggregated, or because they are specified only in partial equilibrium terms. By the same token, however, our model is far tou large to be able to say anything concrete without further specification of its pararneters. Thus, to use the model, we must apply it to a realistic selection of countries and industries using, as far as possible actual data to generate the parameters.

In our original model, we focused on the wotld's 18 major industrialized countries and treated the rest of the world as a residual in order to close the system. ${ }^{8}$ We have since added 16 major developing countries so that the model now covers 34 countries plus a residual rest of world. The countries covered are listed below.

\section{Mạior industrialized countries}

Australia
Lustria
Lelgium-Luxembourg
Canada
Denmark
Finland
France
West Germany
Ireland

Italy

Japan

Netherlands

New Zealand

Norway

Sverlen

Switserland

United Kingdom

United States

\footnotetext{
${ }^{8}$ The reason for this choice was the compilation of detatied information on post Kertnedy Round ad valorem tariffs at the line item level for these countres in mathins peadable form by the General Apreement on Tarifs and Trade (GATT. 1974: These tarifls wers firs? available basec unon $19 \%$ trade. They have since been updated 8976 , which was the raference year or the Tokyo R.sund.
} 
Major developing courtries

$\begin{array}{ll}\text { Argentina } & \text { Mexico } \\ \text { Brazil } & \text { Portugal } \\ \text { Chile } & \text { Singapore } \\ \text { Colombia } & \text { South Korea } \\ \text { Crreece } & \text { Spain } \\ \text { Hong Kong } & \text { Taiwan } \\ \text { India } & \text { Turkey } \\ \text { Israel } & \text { Yugoslavia }\end{array}$

Our industry classification is based upon the International Standard Industrial Classification (ISIC), and is broken down into tradables and nontradables as follows:

ISIC Group

\section{Tratiables}

Description

Agriculture, hunting, forestry, de fishing Food, beverages, and tobacco

Textiles

Wearing apparel, exc. footwear

323

Leather \& leather \& fur products

324

Footwear

Wood products, exc. furniture

Furniture \& fixtures, exc. metal

Paper \& paper products

Printing, publishing

Industrial chemicals 351 ); Other chemical products (352)

Petroleum refineries (353); Misc. prod. of petroleun \& coal (354)

Rubber products

$36 \mathrm{~A}$

Pottery, china \& earthenware (361); Other nonmetallic min. prod. (369)

Glass \& glass products

Iron \& sicel basic industries

Non-ferrous metal basic ind.

Metal products, exc. machinery, etc.

Machinery, exc. electrical

Electrical machinery, apparatus, etc.

38 A Transport equipment

Plistic products, n.e.c. (356); Professional photogr. groods. etc. (385); Otiser manuf. industries (390) 


\begin{tabular}{cl} 
ISIC Group & \multicolumn{1}{c}{$\begin{array}{c}\text { Nontradables } \\
\text { Description }\end{array}$} \\
2 & Mining and quarrying \\
4 & Electricity, gas, and water \\
5 & Construction \\
6 & Wholesale \& retail trade, restaurants \& hotels \\
7 & Transport, storage, \&: communication \\
8 & Finance, insurance, real estate, etc. \\
9 & Community, sorial \& pers nal services
\end{tabular}

Civen appropriate datai for the above countries and industries, ${ }^{9}$ solution of the model shruld, ir principle, he straightforward. By differentiating the equations of the model, we obtained a system of linear equations riating changes in all of the variables of the system. The coefficients in each of these linear equations were evaluated using the data and elasticity information we had collected. All that remained was to solve the system. Since the system was lines.: it could in principle be solved by any of a variety of means.

Ini fact, however, the size of the model made this difficult. With 34 countries and 29 industries, what we have represented here as single equations each become a large number of separate equations to be solved. Depending on how many of these equations were first eliminated by substitution, the number of equations in the model could run to several thousand. A systenn of this size strains the sapacity of even high-speed computers. And while the number of equations can be reduced substantially by prior substitutions, the substitutions themselves involve a tremendous amount of computation. It was to avoid these difficulties that, in earlier applicntions of the model, we introduced a number of approximations to reduce the amount of sinultaneity in the system..$^{10}$

We have since been able to obtain exact solutions. To do so, we first clevised several Fortran st.iroutines that process large partitioned matrices in which many of th partitioned blocks contain only zeros, and which avoids costly but meaningless computations involving these zeros. Second, we used a Fortran prograuming technique known as dynamis:

\footnotetext{
${ }^{9}$ The requisite import anc export data used ve re obtained from United Nations trade tapes for 1976. Information on output and employment was obtained directly or orherwise estimated from the Uni ed Nations, Yearbook of Industrial Statistics, CECD publications on national accounts al d labor statistics, ancl national statistical sources.

${ }^{i U}$ These approximations consisted primarily of using exogenous taiff changes to approximate the change in both expenciture ard the prices of intermediat: goods, and of ignoring demands for interr 1 ediate goods in the demand functions, at certen stages of the solution.
} 
dimensioning to avoid wasting computer-memory space on these empty blocks, even as the contents of all blocks change during the course of the solution. And finally, we applied these techniques first to each of the 34 counuries separately, using only equations $1-13$ to solve for their net: exports in terms of world prices, exchange rates, and exogenous variables, and then used equations $14-17$ to complete the solution. The resulting computer program is costly, but within reason.

\section{APPLICATION OF THE MODEL TO THE TOKYO ROUND"}

The conclusion of the Tokyo Round of Multilateral Trade Negotiations (MTN) marked the seventh round of multilateral reductions in trade barriers that have been negotiated under GATT auspices since the end of World War II. Tariff's on industrial products a $a$ to be reduced on average by a quarter to a third of their post-Kennedy Round (1972) levels, with the reductions to be phased in, beginning in 1980, over a period of up to eight years. In addition, and perhaps of even greater importance, a series of codes were negotiated covering a variety of NTBs, including customs valuation, government procurement, import-licensing procedures, subsidies and countervailing duties, and product standards. A safeguards cude designed to deal with market disruption due to sudden upsurges in imports was also discussed. But it was not agreed upon because the advanced countries wanted authority to apply safeguards seliectively by product and supplying country while the developing counties favored a global policy. Further, many existing NTBs were exempited altogether from the negotiations. These involved especially agricultural products and foodstuffs, textiles arld wearing apparel, footwear, iron and steel products, consumer lectronic products, and shipbuilding.

Since tariffs constitute an exogenous variable in our model, we can use the model to analyze the effects of the reductions negotiated in the Tokyo Round. For this purpose, we began by calculating the tariff changes at the line-item level based on the Brussels Tariff Nomenclature (BTN). These changes were aggregated using own-country total imports as weights, for each of the 22 tradatile irdustries in each country. The resulting changes in tariffs were then entered into the model as exogenous changes. As mentioned, several codes governing NTBs were negotiated in the Tokyo Round. However, since the codes were stated in advisory terms, they

\footnotetext{
${ }^{11}$ The material in this section draws lieavily on Deardorff and Stern (1980b). The effects of assumed reductions in tariffs and NTB's in the Tokyo Round have been treated by Baldwin et a:. (1980), Brown and W/halley (1980), and Cline et al. (1978).
} 
cannot be quantified readily. It turned out that the only changes in NTBs that we could analyze were those involving agricultural concessions granted by other countries to the United States and vice versa and the liberalization of nondefense government procurement that may occur. The values of the bilateral agricultural concessions were treated as a relariation of import quotas in the agricultural sector in each of the countries. For government procurement, we had information by country on the amount of nondefense procurement that govern " ' ts had tentatively agreed to open to foreign suppliers for bidding pu

$N c$ assumed that the amnunt that each country had earmarke: wo id be spent in proportion to the sestor breakdown of governme . expenditure in each country. The estimated amounts of government imports by sector were then determined by applying the import propensities based upon expenditure data for the private sector.

All the foregoing exogenous changes in tariffs and NTBs were entered into the model, which was then sclved by computer. For this purpose, we used the version of the madel based upon fixed-coefficiunt: technology, exogenous wages, and flexible exchange rates. Results were obtained for percentage changes in the indogenous variables in the riodel. Absolute changes in variables were then determined by multiplying the percentage changes times the initial 1976 levels taken as the refererce poin for all calculations. In addition, we made two separate calculation $S$ of the change in economic welfare by country using the results of the model to estinate changes in consumer and prodicer surplus and tariff rev'snues. The first measure (Method 1) used price changes directly from the model but is correct only if supply and demand functions are statiuñary. This is most s.ppropriate for the reductions in tarifis and for changes in agricultural quotas. The second measure (Method 2) allows for shifts in these schedules by estimating price changes from quantity changes and, though iess accurate, is more appropriate when liberalization extends to governnent procurement.

The overall results are summarized in Table 2 for the major industrialized and derelojing countries. The principal findings are as follows ${ }^{12}$ :

(!) Based upor 1976 level s, exports will rise in total by over $\$ 13$ bilion for all the countries listed, which is about a $1.8 \%$ increase. All of this incre ase is accounted for by the inajor industrialized countries, sirice the

\footnotetext{
${ }^{12}$ The results reported here indicate generally less expansion of trade, employment, and weifare than we have reported beft.re in, for example, beardorff and Stern (1979). The reason is that we have revised and im prov ed our method of calculating weights :o be assigr ed to tariff revenues as they affect expenditure and welfare It turns out that we w r: underestimating the importance of lost tariff revenue in our previous calculations.
} 
exports of the mnicr developing countries fall by a small $\$ 0.08$ billion. U.S. exports rise by $\$ 3.1$ and imports by $\$ 2.5$ billion.

(2) The results fort employment are mixed. Total employment rises in only 7 of 18 industrialized countries, including the United States, and in just haif of the develloping ccantries. Employrnent falls in the rest, accounting for an overall decline of about one huridred thousand workers for all countries combired. These changes are uniformly srnall, however, when compared to the sizes of the respective national laboil forces. In no country do the changes, positive or negative, amount to more than a few tenths of one percent. In the United States, employment rises by eleven thousand workers, but this is only one hundredth of one percent.

(3) Econoinic welfare as measured by changes in consumer and producer surplus and tariff revenues will be increased in all the major industrialized countries except Australia, the Netherlands, and New Zealand. The total welfare gain for the industrialized countries is estimated at between $\$ 1.1$ and $\$ 4.3$ billion per annum, which is les! than one tenth of one percent of their combined grosis domestic product. Most of the diveloping countries will experience a decline in economic welfare. The disveloping countries with an increase in economic welfare are Argentina, Israel, and Mexico, and possibly several others.

(4) Exchange rates will change to a very small extent. The U.S. dollar will de preciate very slightly $(0.3 \%)$, as will such currencies as the Frencia franc and British pound. The German mark and the yen will appreciate very siightly. The exchange rates of most developing countries will remain more or less constant because of controls over foreign exchange licensing.

(5) Import and therefore consumer prices will fall to a limited extent in all of the industrialized courtries except New Zealand. For the United States, the cecline is less than $0.1 \%$. For the claveloping countries, prices will fall oniy in Argentina, Colcribia, Mexico, and Taiwan, but these changes and the rises elsewhere are tremely amall.

All of the above changes, small as they are, ass sume that the changes in tariffs and NTBs that were negotiated in the Tokyo Round are to be implemented at once. In fact they will be phased in over a period of up to a decasie, so that the effects that will occur in ary one year will be ever smaller than noted.

The country results in Table 2 mask much ind is ry detail. Indeed, one of the most important features of our model is that we can calculate the absoiute and relative employment effects across the 22 tradable and $T$ nontradable sectors in each of the 34 countries in the rnodel. These results are too detailed for inclusion here, but are available upon request. To give some flavor of the employment effects by sector, we may note that in the United States, for example, the largest increases were recorded, in 
thousands of workers, for agriculture (53), chernicals (4), nonelectrical machinery (5), and transport equipment (4). There were negative employment effects in food and kindred products $(-2)$, textiles and wearing apparel $(-5)$, nonmetallic mineral products $(-1)$, miscellaneous manufactures (-4), and for all the rontradable industries except mining and quarrying. ${ }^{13}$ All of the foregoing changes for the United States are very small in absolute terms, it may be noted, and thus also in percentage terms, except in agriculture, where the rise in employnent is $1.6 \%$ over the 1976 level.

The effects on the individual sertors in the other countries can be similarly discerned from the underly ing details. While space constraints do not permit us to singie out particular resuls, it is noteworthy that most of the negative employment changes in the developing countries were concentrated in agriculture and textiles and wearing appare. We have already mentioned that the NTBs affecting these sectors were left intact in the Tokyo Round. With tariffs being reduced in most other sectors, there is a tendency for world prices (exclusive of tariffs) in these other sectors to rise and for consumer prices (inclusive of tariffs) to fall. As a consequence, the pattern of world demand shifts sumewhat away from: the exempted sectors and toward those in which tariffs are reduced. This fall in demand occurs in what are often th: most important export sectors in the de reloping countries, and its adverse effects are augmented by the rise in prices of other manufactures which nıy serve as inputs to these sensitive sectors. It is the specialization in these sectors by developing countries that in large part accounts for the overall declines in employment and welfare that the Tokyo Round cause; in these countries. By the same token, it should be mentioned that certairi of the developing countries that have been successfu! in expanding their exports of durable manufactures enjoy the status of free riders in the Tokyo Round and will be encouraged further along these lines.

We made reference to the atively small employment effects that are likely to occur in individual sectors in the United States, except in the case of agriculture. However, inspection of the detailed results for other counties suggests that there are nurnerous instances in which the perceritage employment cianges in particular sectors may be substantiall, greater than $1 \%$. A possible way to assess these changes, without getting bogged down in detail, is to look separately at the gross employment

\footnotetext{
${ }^{13}$ There were numerous instances of nega:ive employment effects in the nontradable sectors across countries. These negative effects reflect gene ally the substitution towards tradable goods and away $\mathrm{rcm}$ nontradables clue to the redu.tion in the prices of tradable gocd, that will result from the Tokyo Round.
} 


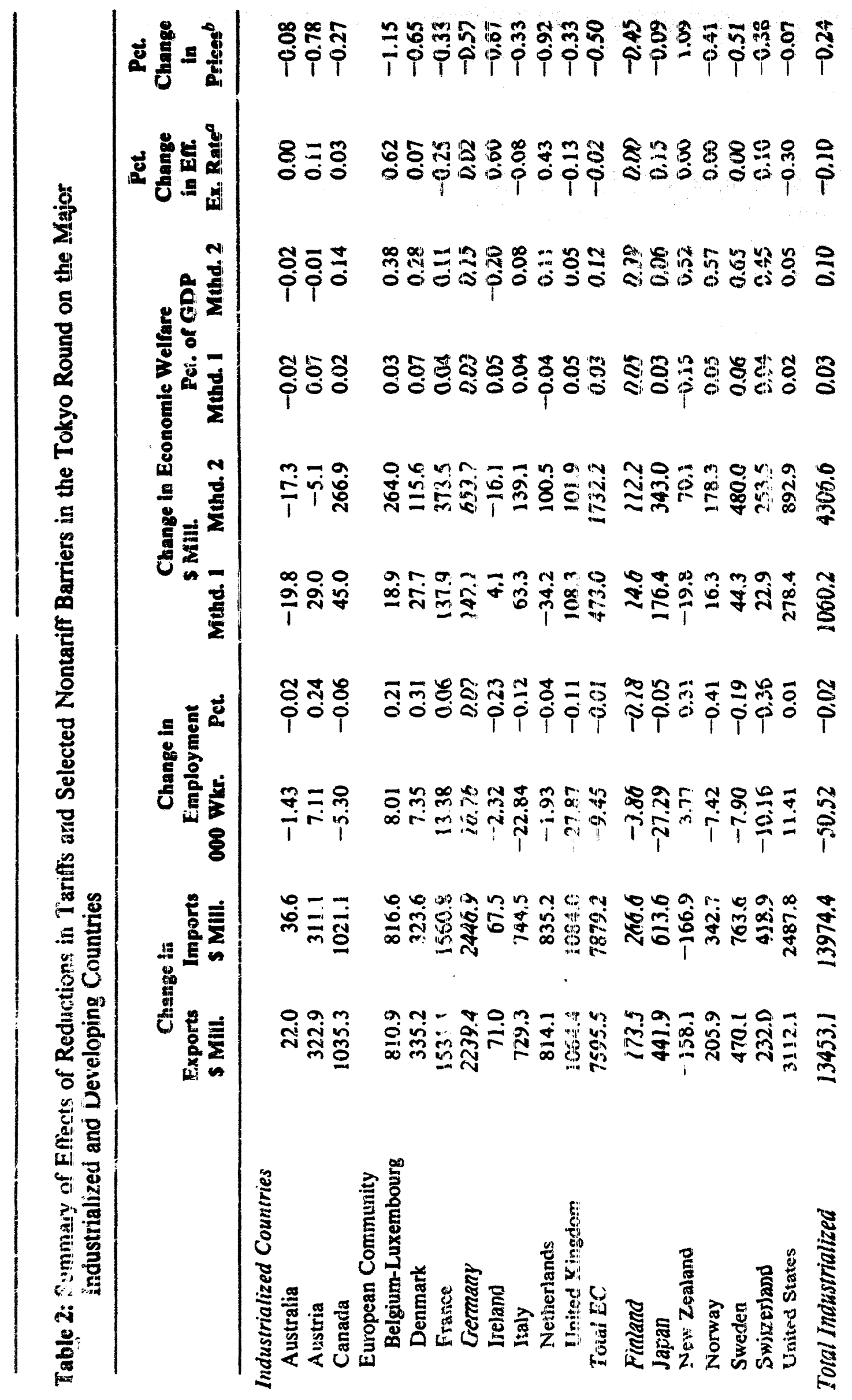




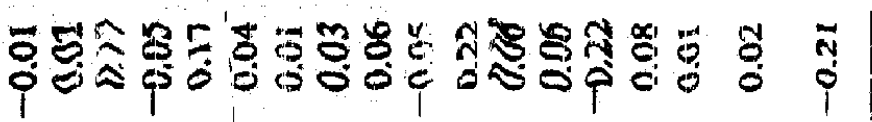

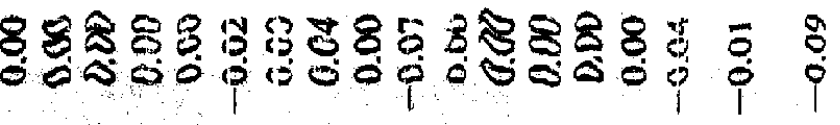

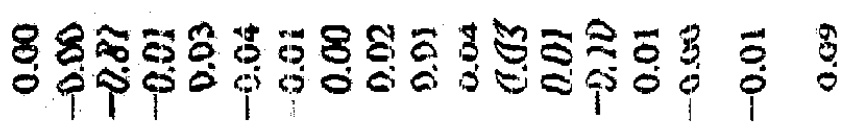

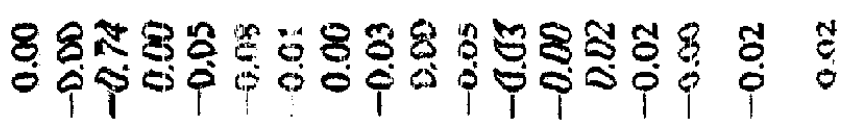

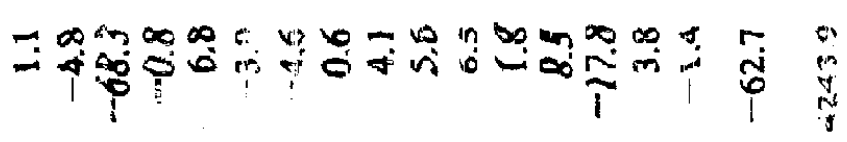

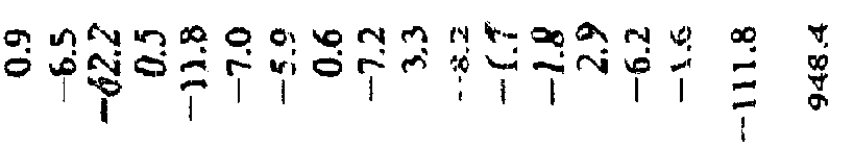

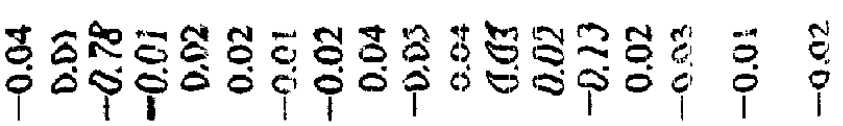

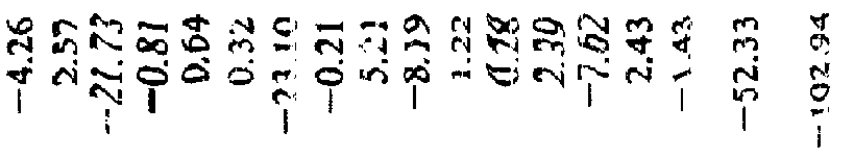
彳

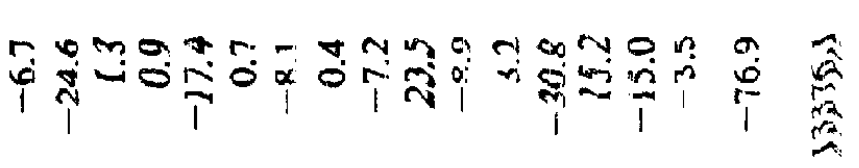

芯

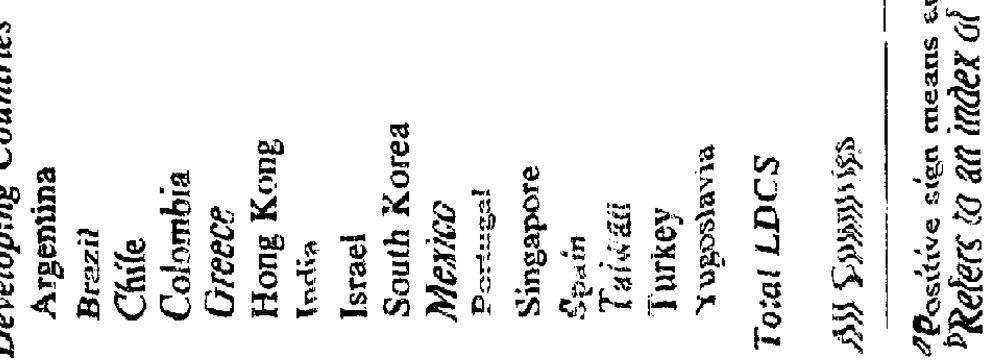


Table 3: Summary of Employment Effects of the Tokyo Round on the Major Industrialized anci Devsloping Countries

\begin{tabular}{|c|c|c|c|c|c|c|}
\hline & $\begin{array}{l}\text { Net C } \\
\text { in Empl } \\
000 \text { of } \\
\text { Workers }\end{array}$ & $\begin{array}{l}\text { Iminge } \\
\text { yyment } \\
\text { Pet. }\end{array}$ & $\begin{array}{l}\text { Gross ! } \\
\text { in Emplo } \\
\text { O:10 of } \\
\text { Workertis }\end{array}$ & $\begin{array}{l}\text { erease } \\
\text { Pet. }\end{array}$ & $\begin{array}{l}\text { Gross D } \\
\text { in Emple } \\
000 \text { of } \\
\text { Workers }\end{array}$ & $\begin{array}{l}\text { ecline } \\
\text { yment } \\
\text { Pet. }\end{array}$ \\
\hline \multicolumn{7}{|l|}{ Industrialized Countries } \\
\hline Australia & -1.4 & -0.02 & 3.3 & 0.05 & -4.7 & -0.08 \\
\hline Austria & 7.1 & 0.24 & 19.1 & 0.65 & -12.0 & -0.41 \\
\hline Canada & -5.3 & -0.06 & 25.5 & 0.27 & -30.8 & -0.32 \\
\hline \multicolumn{7}{|l|}{ European Community } \\
\hline Belgium-Luxembourg & 8.0 & 0.21 & 34.6 & 0.89 & -26.6 & -0.69 \\
\hline Denmark & 7.4 & 0.31 & 17.5 & 0.73 & -10.1 & -0.42 \\
\hline France & 13.4 & 0.06 & 64.4 & 0.31 & -51.0 & -0.24 \\
\hline Germany & 16.8 & 0.07 & 107.0 & 0.44 & -90.2 & -0.37 \\
\hline Ireland & -2.3 & -0.23 & 4.1 & 0.41 & -6.5 & -0.63 \\
\hline Italy & -22.8 & $-n 12$ & 45.2 & 0.24 & -68.1 & -0.36 \\
\hline Netherlands & --1.9 & -0.04 & 24.7 & 0.54 & -26.6 & -0.59 \\
\hline United Kingdom & -27.9 & -0.11 & 50.9 & 0.21 & -78.7 & -0.32 \\
\hline Total EC & -9.5 & -0.01 & 348.3 & 0.35 & -357.7 & -0.36 \\
\hline Finland & --3.9 & -0.18 & 7.7 & 0.36 & -11.6 & -0.54 \\
\hline Japan & -27.3 & -0.05 & 34.9 & 0.07 & -62.1 & -0.12 \\
\hline New Zealand & 3.9 & 0.31 & 10.1 & 0.84 & -6.3 & -0.52 \\
\hline Norway & -7.4 & $-0.4 i$ & 5.8 & 0.32 & -13.2 & -0.74 \\
\hline Sweden & -7.9 & -0.19 & 17.4 & 0.43 & -2.5 .3 & -0.62 \\
\hline Switzerland & -10.2 & -0.36 & 9.0 & 0.32 & -19.1 & -0.68 \\
\hline United States & 11.4 & 0.01 & 123.1 & 0.14 & -111.7 & -0.13 \\
\hline Total Industralized & -50.5 & -0.02 & 604.2 & 0.22 & -65.4 .8 & -0.24 \\
\hline \multicolumn{7}{|l|}{ Developing Countries } \\
\hline Argentina & -4.3 & -0.04 & 1.4 & 0.01 & -5.6 & -0.05 \\
\hline Brazil & 2.6 & 0.01 & 8.0 & 0.02 & -5.5 & -0.01 \\
\hline Chile & -217 & -0.78 & 0.9 & 0.03 & -22.6 & -0.81 \\
\hline Colombia & -0.8 & -0.01 & 3.0 & 0.04 & -3.8 & -0.05 \\
\hline Greece & 0.6 & 0.02 & 4.0 & 0.10 & -3.4 & -0.08 \\
\hline Hong Kong & 0.3 & 0.02 & 2.5 & 0.19 & -2.1 & -0.16 \\
\hline India & $-23 . i$ & $-0 . \therefore$ & 20.7 & 0.01 & -43.8 & -0.02 \\
\hline Israel & -0.2 & -0.02 & 0.5 & 0.04 & -0.7 & $-1) .06$ \\
\hline South Korea & 5.2 & 0.04 & 10.0 & 0.08 & -4.8 & -0.04 \\
\hline Mexico & -8.2 & -0.05 & 26.1 & 0.15 & -34.3 & -0.20 \\
\hline Portugal & 1.2 & 0.04 & 4.1 & 0.13 & -2.9 & -0.09 \\
\hline Singapore & 0.3 & 0.03 & 1.1 & 0.12 & -0.8 & -0.09 \\
\hline Spaia & 2.4 & 0.02 & 7.1 & 0.06 & -4.7 & -0.04 \\
\hline Tuivan & -7.6 & -0.13 & 5.3 & 0.09 & -13.0 & -0.23 \\
\hline Turkey & 2.4 & 0.02 & 6.4 & 0.04 & -3.8 & -0.03 \\
\hline Yugoslavia & -1.4 & -0.03 & 2.2 & 0.05 & -3.7 & -0.08 \\
\hline Totai LDCS & -52.3 & -0.01 & 103.2 & 0.03 & --155.6 & -10.04 \\
\hline All Countries & -102.9 & -0.02 & 707.5 & 0.11 & --810.3 & -0.13 \\
\hline
\end{tabular}

${ }^{2}$ Refers to sum of changes $n$ the home and export sectors $w_{\text {ithin }}$ industries. 
ircrea:es and declines by county. This thas been done in Table 3, in which the third column reports the sum of all positive sectoral employment changes and the ifth column reports the sum of all regative changes. Thus, the latter ligure represents the total number of workers in the country who would have to change jobs ais a result of the Tokyo Round. These gross charges are of course considerably larger than the net changes in the first column, but they still amount to only a fraction of a percent of employment in each country. It should therefor be fairly easy to accommodate these changes within the norrial process of labor-market turnover. And once again, if we consider that the Tokyo Round reductions in tariffs and NTBs will be phased in over several yiears, it seems urlikely that any serious distuptions in labor markets will occur.

The smallness of our results need not be surprising if we consider the reasons for it. First of all, the tariff reductions which were negotiated in the Tokyo Round are themseives quite small. That is, average tariffs are to be cut from approximately $8 \%$ to $5 \%$. Even if all tariff changes were reflected fully in import-price chainges, the latter would fall by only $2 \%$. But even this will not happer, since tariff cuts in many industries and countries simuitaneously cause worli prices to be bid up and offset r.sore than half of the tariff changes. Even in countries with above average tariff cuts such as the United States, exchange rates move to reduce differences frorn the world average. Finally, the price changes that do occur can have only limited effects on output and employment since their roles as output prices and input prices counteract. All things considered, then, it is to be (xpected that the effects of the Tokyo Round on trade, employ ment, and welfare should be ineasured in tenths, or even hundredths, of c. percent.

\section{SENSITIVITY OF RESULTS TO CHANGES IN PARAMETERS}

The question naturally arises as to how sensitive our results may be to certain key parameters. In order to test for sensitivity, we ran three separate experiments. We first doubled all supply elasticities, then doubled all elasticities of sul titution between home and imported goods (with the original supply elas cities unchanged), and finally doubled both supply and substitution elesticities. The results of these experiments are too detailed for presentation here, and we therefore describe them only qualitatively.

Doubling the supply elasticities enlarges the: overall net employment increases and declines in individual countries, but the effects are still comparatively small. The effects on welfare are not unusually sensitive to the increased supply elasticities. Doubling the elasticities of substitution between imported and horre goods has a negligible effect on the overall net changes in employment. "et there is a sizable increase in one of our two 
measures of economic welfare because the higher substitution elasticities imply a shift of a more elastic schedule and thus a greater welfare effect. Doubling both the supply and substitution elasticities has a minor effect on the einployment results, but the welfare calculation just noted is larger.

It should be pointed out that the elasticities of supply and substitution used in our model have been derived from empirical data and are thus reasonabiy firmly grounded on realistic data. Our confidence in the model is enhanced by the comparative stability of the employment results. By the same token, our welfare calculations have more of an ad hoc quality to them since they are not derived in a rigorous theoretical manner from the model itself. It is neverthless noteworthy that our one welfare measure, which assumes given demand and supply functicns and is most appropriate for changes in tariffs and quotas, yields fairíy stable results. Our second welfare measure, which assumes an implicit shift in demand, was designed to deal with the effects of liberalizing government procurement. It is apparently fairly sensitive to the elasticity parameters and should be interpreted cautiously therefore.

\section{IMPLICATIONS OF THE TOKYO ROUND}

Our analysis of the reductions in tariffs and quantifiable NTBs negotiated in the Tokyo Round suggests that there will be relatively small but beneficial economic effects for practically all the major industrialized countries and for some of the major developing countries. It is possible as well that there may be significant benetits from the particular NTB codes that we could not include in our calculations. The principal significance of these codes is that they signal the willingness and intent of participating governments to reduce their interference with trade. The benefits must ultimately depend therefore on whether governments will in fact adhere to the codes.

In order to put the Tokyo Round in perspective, we should recognize what it failed to accomplish. We ncted earlier that negotiations on a safeguards code broke down on the issue of selective versus global implementation. Also, and perhaps even more important, several key sectors now subject to NTBs were exempted explicitly from the negotiations. We have not been able to use our model to investigate the significance of the NTBs exempted in the Tokyo Round because of data limitations. However, using a model somewhat similar to ours, Brown and Whalley (1980) have calculated that removing existing NTBs altogether would increase worid welfare by about $\$ 16$ billion (in 1973 prices), which is far in excess of their estimated $\$ 1.5$ billion gain per annum resulting from the Tokyo Round concsssions. The Tokyo Round must be viewed 
accordingly as having dealt with a relatively li nited part of all interferences with international tride.

\section{CONCLUSION}

We have set out in this paper a computational model of world production, trade. - emplnyment that has been constructed to analyze the likely effects a multilateral changes in tariffs. NTBs, and other exogenous ever ts. The model focuses on the microeconomic interactions among industrius and countries. It has undergone a series of refinements since its inception, and we have reported here its structure and specification as of early 1981. If time and resources perm.t, the model will be modified and expanded stili more in the future as our experience with it and the world economy suggests possible averues for improvement.

We have applied the model to the reductions in tariffs and NTBs that were negotiated in the Toky' Round and that have been implemented beginning in 1980. Our findings are that the Tokyo Round will have smal: but beneficial effects on trade, domestic prices, and economic welfar: in the United States and ractically all the other major industrialized coun'ries. Employment will rise and fall by small amounts in various it vies and countries, with the United States posting a change that is positive but almost negligible in sizs. There will be small gains to some bui by no means all of the major devcloping countrics. We were unasle to quantify nany of the NTB codes negotiatid in the Tokyo Rcund so that their likely effects cannot be evaluated unambiguously at present. By the same token, there were several important NTB's tha: were left intact in the Tokyo Round. Benefis from further liberalization of international trade could be substantial if these ex isting NTBs were reduced or renoved.

\section{APPENDIX: EXPLICIT IUNCTIONAL FORMS}

The following are the diffe antiated versions of equations 1.4 and $9.1^{\circ}$ of Table 1. The operator e repre.ents the differentici of the natural logarithm of the ariable that follows it. Thet is, for any veriable $x$.

$$
\begin{array}{rl}
e x & a(\ln x)=d x / x . \\
e S_{i j}^{X} & =\varepsilon_{i j}+\delta\left(1-b_{i j}^{O}\right) / b_{i j}^{O} l e p_{i j}^{X}-\left(\varepsilon_{i j}+\delta\left(1 / b_{j}^{O}\right)\right) \\
& \times \sum_{i=1}^{n} b_{i k j}\left(\theta_{i k}^{H} e p_{i k}^{H}+\theta_{i k}^{M} e p_{i k}^{M}\right)-\varepsilon_{i j} b_{j}^{O} e w_{i j}+e K_{i j}^{X} .
\end{array}
$$




$$
\begin{aligned}
e \delta_{i j}^{H} & =\left[\varepsilon_{i j}+\delta\left(1-b_{i j}^{O}\right) / b_{i j}^{O}\right]\left(e p_{i j}^{H}+e t_{i j}^{H}\right)-\left[\varepsilon_{i j}+\delta\left(1 / b_{i j}^{O}\right)\right] \\
& \times \sum_{k=1}^{n} b_{i k j}\left(b_{i k}^{H} e p_{i k}^{H}+\theta_{i k}^{M} e p_{i k}^{M}\right)-\varepsilon_{i j} b_{i j}^{O} e w_{i j}+e K_{i j}^{H},
\end{aligned}
$$

where

$\varepsilon_{i j}=$ Supply elasticity of industry $j$, country $i$,

$b_{i k j}=$ Input-ourfaut coefiticient for use of good $k$ as input to industry ${ }^{i}$ in covintry $i$,

$b_{i, j}^{O}=$ Value-ndded share of industry $j$, country $i$,

$\theta_{i k}^{M}, O_{i k}^{H}=$ Initial shares of demand in country $i$ for imported and rome-produced products of industry $j$, and

$\delta=\left\{\begin{array}{l}1 \text { for Cobb-Douglas technology } \\ 0 \text { for Fixed Coeficient technology. }\end{array}\right.$

$$
\begin{aligned}
e D_{i j}^{M}= & -\theta_{i j}^{H} \sigma_{i j}\left(e p_{i j}^{M}-e p_{i j}^{H}\right)-\left[(1-\delta) v_{i j}^{O}+\delta\right]\left(\theta_{i j}^{H} e p_{i j}^{H}+\theta_{i j}^{M} e p_{i j}^{M}\right) \\
& +v_{i j}^{O} e E_{i}+\sum_{k=1}^{n^{\prime}} v_{i j k}\left[\gamma_{i k}^{X}\left(e S_{i k}^{X}+\delta e p_{i k}^{X}\right)\right. \\
& \left.+\left(1-\gamma_{i k}^{X}\right)\left(e S_{i k}^{H}+\delta e p_{i k}^{H}\right)\right]+e G_{i j} . \\
e D_{i j}^{H}= & -\theta_{i j}^{M} \sigma_{i j}\left(e p_{i j}^{H}-e p_{i j}^{M}\right)-\left[(1-\delta) v_{i j}^{O}+\delta\right]\left(\theta_{i j}^{H} e p_{i j}^{H}+\theta_{i j}^{M} e p_{i j}^{M}\right) \\
& +v_{i j}^{O} e E_{i}+\sum_{k=1}^{n^{\prime}} \nu_{i k}\left[\gamma_{i k}^{X}\left(e S_{i k}^{X}+\delta e p_{i k}^{X}\right)\right. \\
& \left.+\left(1-\gamma_{i k}^{X}\right)\left(e S_{i k}^{H}+\delta e p_{i k}^{H}\right)\right] \\
& -\left(\theta_{i j}^{M} / \theta_{i j}^{H}\right) e G_{i j},
\end{aligned}
$$

where

$\sigma_{i j}=$ Elasticity of substitution in cowntry $i$ betweer inported and homeproduced products of industry $j$,

$v_{i j k}=$ Demand by in iustry $k$ for products of industry $j$ zs al share of total demand for industry $j$ in countiry $i$, 
$\nu_{i i}=$ Share of tinal demand in total demand for industry $j$ in country $i$, and

$\gamma_{i j}^{K}=$ Share of sxports in total production of industry $j$, country $i$.

$$
\begin{aligned}
& e t_{i j}^{M e q}=e t_{j}^{M}+\left[\theta_{i j}^{M} / \eta_{i j}\left(1-\theta_{i j}^{Q M}\right)\right]\left(e Q_{i j}^{M}-e D_{i j}^{M}\right), \\
& e D_{i j}^{M}=\frac{1}{M_{i}} \sum_{k=1}^{n}\left[X_{i k} e S_{i k}^{X}+\left(X_{i k}-M_{i k}\right) e p_{k}^{W}+d B_{i}^{K O}\right], \\
& e t_{i j}^{X}=e t_{i j}^{X}+\left[\theta_{i j}^{Q X} / \varepsilon_{i j}\left(1-\theta_{i j}^{Q X}\right)\right]\left(e Q_{i j}^{X}-e S_{i j}^{X}\right),
\end{aligned}
$$

whare

$\partial_{i j}^{Q M}, \theta_{i j}^{Q X}=$ Shares of imports and exports of industry $j$ subject to quantilative restrictions in country $i$,

$\eta_{i j}=$ Price elasticity of demand for imports of good $j$ in country $i$,

$M_{i}=$ Total imports of country $i$, and

$X_{i k}, M_{i k}=$ Values of exports and imports of industry $k$, country $i$.

$$
\begin{aligned}
e D_{i j}^{L}= & \gamma_{i j}^{X}\left\{\left[1 /\left(1+\delta / b_{i j}^{o} \varepsilon_{i j}\right) \theta_{i j}^{L}\right]\left\{e S_{i j}^{X}+\delta\left(e p_{i j}^{X}-\imath w_{i j}\right)\right]\right. \\
& \left.-\left[\left(\theta_{i j}^{K}-\delta \theta_{i i}^{L}, b_{i j}^{o} \varepsilon_{i j}\right) /\left(1+\delta / b_{i j}^{O} e_{i j}\right) \theta_{i j}^{L}\right] e K_{i j}^{X}\right\} \\
& +\left(--\gamma_{i j}^{X}\right)\left\{\left[1 /\left(1+\delta / b_{i j}^{O} \varepsilon_{i j}\right) \theta_{i j}^{L}\right\}\left\{e S_{i j}^{H}+\delta\left(e p_{i j}^{H}-e w_{i j}\right)\right]\right. \\
& \left.-\left[\left(\theta_{i j}^{K}-\delta \theta_{i j}^{L} / b_{i j}^{O} \varepsilon_{i j}\right) /\left(i+\delta / b_{i j}^{O} \varepsilon_{i j}\right) \theta_{i j}^{L}\right] e K_{i j}^{H}\right\},
\end{aligned}
$$

where

$\theta_{i}^{L}, \theta_{i j}^{K}=$ Labor̀ and capital shares of value-added in industry $j$, cuntry $i$.

Equation $\mathrm{A9}$ a is deriv ed as fillows. Let a typical import demand depend on the tariff equivalent, with eiasticity $\boldsymbol{\eta}$, and a list, $\lambda$, of other variables including price:

$$
e D^{M}=\eta e t^{M e q}+\lambda \text {. }
$$

Define an implicit tariff, ${ }^{M}$, that would hold imports to a given quantity, $Q^{M}$, in (B1):

$$
e^{M}=\eta t^{Q M}+\lambda,
$$

and define $t^{M e q}$ as the weignted average of $t^{M}$ and $t^{Q M}$ :

$$
e t^{M e q}=\left(1-\theta^{Q M}\right) e t^{M}+\theta^{Q M} e t^{Q M} .
$$

Elinainating ${ }^{2 M}$ and $\lambda, B 1-B 3$ can be solved to yield A9a. Equation A10a can be derived similarly.

\section{REFERENCES}

Baldwin, Robert E., Mutti, John H., ard Kicherdson, J. David (1980) Welfare Leffects on the Unired States of a Sighificant Multilateral Tariff Feduction, Journal of Internaticanal Eicononics 10 (August). 
Biown, Fred and Whalley, John (1980) General Equilibriun Evaluations of Tariff-Cutting Proposals in the Tokyo Round and Comparisons to More Extensive Liberalization of World Trade, Economic Joumal 90 (December).

Clint, Willizm R., Kawanabe, Nobon, Kronsjö, T.O.M., and Williams, Thomas (1978) Trade Negotiations in the Tokyo Round: A Quattitative Assessment. Washington: The Brookings Institution.

Deardorf, Alan V. and Stern, Robert M. (1979) An Economic Anal vsis of the Effects of the Tokyo Round of Multilateral trade Negotiations on the Unit:d States and the Other Major Industrialized Countries. MTN Studies 5, Committee on Finance, U.S. Senate, 96th Congress, Ist Session. Washingtion: U.S. Government Printing Office.

-_- (1980a) Changes in Trade and Employment in the Major Industrialized Countries, 1970-76. Presented at the Intemational Economic Associacion. Sixth World Congress of Economists, Mexico City, (August).

-- (1980b) Economic Effects of the Tokyo Round. In prosesis.

-.-., $(1980 \mathrm{c})$ Tariff and Exchange-Rate Frotection under Fixed and Flexible Exchange Rates in the Major Indastrialized Countries, in The International Transmission of Economic Disturbances (J. Bhandari and B. Putnam, Eds.). Forthcoming.

- - , and Baum, Christopher F. (1975) A Simulation Model of World Trade and Production. Mimleo.

- - , and Greene, Mark N. (1979) The Sensitivity of Industrial Output and Employment to Exchange-Rate Changes in the Major Industrialized Countries, in Trade and Payments Adjustinent Uizder Flexille Exchange Rates (J.P. Martin and M.A.M. Smith, Eds.). London: Macmillar. 1979.

GATT (1974) Basic Documentation for the Tariff Study. Geneva: GATT.

Stern, Robert M. et al. (1976) Prise Elasticities in International Trade: A Compilation and Annotcted Bibliography of Recent Research, London: Macmillan.

Zarernbka Jaul, and Chernicoff, Helen P. (1971) Further Results on the Empirical Relevance of the CES Production Function," Review of Economics and Statistics LIII (Fiebriary). 